$\mathrm{PN}-001$

ユーモアコーピングタイプと心理的 Well-being の関連一非階層的クラス ター分析によるユーモアコーピング のタイプ分類一

\author{
$\bigcirc$ 本郷亜維子 ${ }^{1}$ \\ ( ${ }^{1}$ 放送大学) \\ キーワード : ユーモアコーピング，心理的 Well-being
}

本研究では, ユーモアコーピングに使用される 4 つのユーモア形態の 組み合わせタイプによる心理的 Well-being (PWB) の差について, 調查 分析を行うことを目的とした。20-60代の成人 1200 名（男女各600名，平 均44.83歳, $S D=13.95$ 歳) を対象にユーモアコーピング尺度（本郷, 2019）とRyff の PWB 尺度（岩野ら，2015）を用いWeb 調查を行った。 非階層的クラスター分析により（1）全因子（自己高揚，協調，攻撃，自 嘲的ユーモア）低得点タイプ；(2) 全因子平均点タイプ；(3) 全因子高得 点タイプ ; (4) 攻撃的ユーモア低・ 3 因子高得点タイプの 4 つのクラス ターを特定した。多重比較分析の結果, タイプ(4)の PWB 全因子（人生 における目的, 人格的成長, 自律性, 自己受容, 環境制御力, 積極的な 他者関係) 得点が最も高く，タイプ(3)，(2)と続き，タイプ(1)が最も低 かった。問題に対しユーモアを用いたコーピングを多く使用するタイプ は, ユーモアの形態に関わらず心理的幸福感が比較的高く，なかでも攻 撃的ユーモア形態のみあまり使用しないというタイプの心理的幸福感が 最も高いことが明らかとなった。本研究の結果から, 自己を貶める自嘲 的ユーモアの有益性及び相手を貶める攻撃的ユーモアの有害性が示唆さ れた。

連絡先 E-mail : aikohongo0802@gmail.com

\section{PN-003行動的検出理論モデルにおける感受 性パラメータの検討}

神谷 直樹 ${ }^{1}$

(1中央大学)

キーワード : 検出理論, マッチング法則, 感受性

検出理論（Macmillan \& Creelman, 2005）に基づいたマッチング法則モ デルがいくつか提案されている（例えば, Davison \& McCarthy (1980), Davison \& Tustin (1978) や Nevin (1981) など)。これらの行動的検出 理論モデルの目標は, 効果の法則に弁別刺激の効果を導入し, 弁別刺激 と強化子による行動制御モデルを構築することと考えられる。これらの モデルでは一般化マッチング法則における 2 つのパラメータのうち, 特 に感受性パラメータの扱いが異なっている。感受性は, 行動と行動結果 のマッチング関係において, 行動結果が行動に与えていた影響を調整す る重要なパラメータの一つであるが, モデルによっては感受性パラメー 夕項が消失してしまうことすらある。本研究では, 過小マッチングなど が表現可能なパラメータを持ちうる反応生成分布を想定することによっ て, 行動的検出理論モデルにおける感受性パラメータなどについて検討 した。パラメータの推定には階層ベイズモデルを使用した。その結果, 想 定した反応生成分布のパラメータを一般化マッチング法則の感受性パラ メータと同等に扱えることが示唆された。

連絡先 E-mail：nkamiya.03d@g.chuo-u.ac.jp
注）＃印は日本心理学会会員以外であることを示す。

PN-002「何回デッキ選択をしたと思います か?」ギャンブル課題における主観 的試行数とリスクテイキング傾向の 関連

\author{
清水 佑輔 ${ }^{1}$, 岡田 謙介 $^{1}$ \\ ( ${ }^{1}$ 東京大学) \\ キーワード : ギャンブル課題, 主観的試行数, リスクテイキング
}

\begin{abstract}
In laboratory settings, the Iowa Gambling Task (IGT) has been conducted to measure gambling-related decision making; the Soochow Gambling Task (SGT) is a modified version of the IGT used to distinguish two common choice strategies: expected-value-based and loss-frequency-based. In addition to the SGT, we also investigated the negative-expected-value SGT (NEVSGT), in which the expected values of all four decks are negative. The NEVSGT is thought to be closer to real-life gambling situations. In this study, we considered the relationship between the subjectively-experienced number of trials (SNT) in each task and risk-taking propensity using the Risk Propensity Questionnaire. Thirty Japanese university students $(22$ males and 8 females) participated in the experiment. Each participant completed two tasks on a PC whose order was counterbalanced across participants. Two participants were excluded who chose the same deck too many times, leaving 28 final participants. Our results show that risk-taking propensity was positively correlated with the accuracy of the SNT, and more prominently so for the NEV-SGT. People who liked to take risks tended to pay more attention to the gambling task and had higher arousal, which could lead to a higher accuracy of the SNT. Furthermore, most of the participants underestimated the number of trials. Based on these results, we discuss the possibility of using the SNT in gambling tasks as a predictor of gambling-related psychological traits. 連絡先 E-mail : yuhos1120mizu@g.ecc.u-tokyo.ac.jp
\end{abstract}

\section{PN-004 ソーシャルストーリーで描いた感謝 生起状況における感謝表出スキルの 実行可能性}

\author{
酒井 智弘 ${ }^{1}$, 相川 充 ${ }^{1}$ \\ (1筑波大学) \\ キーワード : 感謝表出スキル, ソーシャルストーリー, 感謝生起状況
}

本研究の目的は, 個人が特定の感謝生起状況にいる他者に対して, 感 謝表出スキルをどのように実行しているのかを検討することであった。こ の目的を検討するために, 本研究では, 大学生309名 $\left(M_{\mathrm{age}}=19.69 \pm\right.$ 1.78）に質問紙調査を行った。質問紙調查では, 感謝表出スキル尺度 (Sakai \& Aikawa, 2019) に回答を求め, ソーシャルストーリーという 手法（Gray \& Garand, 1993; Karal \& Wolfe, 2018）で描いた特定の感 謝生起状況にいる他者に対して取る行動（「ありがとうと言う」「感謝の 気持ちを言葉で繰り返して伝える」「感謝した理由を言う」「感謝した相 手の名前を呼ぶ」「相手に今度お礼をすることを約束する」等）を選択す るように求めた。本研究で作成したソーシャルストーリーには, 感謝さ れる側に,「友人」「先輩」「恋人」等を登場させて, 計 8 個のストーリー を作った。その状況で, どのような行動で感謝表出スキルを実行するの かを決定木分析によって検討した。その結果, ストーリーの内容によっ て, 感謝表出スキルの実行可能性が高い人が選択する行動は異なってい た。感謝表出スキルの実行可能性が高い人が状況によって感謝感情の表 出方法を変えていることを議論した。 